\title{
First record of the non-indigenous jellyfish Blackfordia virginica (Mayer, 1910) in the Baltic Sea
}

Cornelia Jaspers ${ }^{1,2^{*}} \mathbb{0}$, Bastian Huwer ${ }^{2}$, Nancy Weiland-Bräuer ${ }^{3}$ and Catriona Clemmesen ${ }^{1}$

\begin{abstract}
Marine invasions are of increasing concern for biodiversity conservation worldwide. Gelatinous macrozooplankton contain members, which have become globally invasive, for example the ctenophore Mnemiopsis leidyi or the hydromedusae Blackfordia virginica. B. virginica is characterised by a large salinity tolerance, with a brackish-water habitat preference, and by a metagenic life history strategy with an alternation between sexually reproducing planktonic medusae and asexually reproducing benthic polyps to complete the life cycle. In this study we analysed 8 years of ichthyoplankton survey data (2010-2017) from the Kiel Canal and 14 ichthyoplankton summer surveys in the central Baltic Sea (2008-2017). We report the first presence of B. virginica in northern Europe, namely from the southwestern Baltic Sea and the Kiel Canal. In the Kiel Canal, B. virginica was first sporadically sighted in 2014 and 2015 and has developed persistent populations since summer 2016. Changes in size-frequency distributions during summer 2016 indicate active recruitment in the Kiel Canal at salinities between 7 and 13 and temperatures $>14^{\circ} \mathrm{C}$. Close vicinity to and direct connection with the southwestern Baltic Sea, where B. virginica was observed during 2017, indicate that the Baltic Sea and other brackish-water habitats of Northern Europe are at risk for colonisation of this non-indigenous species. Our results highlight that monitoring activities should consider gelatinous macrozooplankton for standard assessments to allow for the detection of non-indigenous species at an early stage of their colonisation.
\end{abstract}

Keywords: Hydromedusa, Species translocations, Invasive species, Ballast water, Kiel Canal

\section{Background}

Global change has wide ranging consequences for the productivity and functioning of the worlds' oceans. Among the pressures associated with global change are overfishing, eutrophication, coastal habitat modification and species translocations [1]. The transport of species outside their native dispersal ranges impacts recipient ecosystems and is leading to a homogenization of the worlds' biota [2, 3]. Lately, it has been documented that the rate at which new species are recorded outside their natural habitat boundaries is steadily increasing, with no signs of saturation [4]. Even though it is only a small fraction of the originally arriving non-indigenous species

\footnotetext{
*Correspondence: coja@aqua.dtu.dk; cjaspers@geomar.de

${ }^{1}$ Evolutionary Ecology of Marine Fishes, GEOMAR - Helmholtz Centre for Ocean Research Kiel, Düsternbrooker Weg 20, 24105 Kiel, Germany Full list of author information is available at the end of the article
}

which actually attain large population densities [5], the impact of those species which actually do become invasive and achieve pest status can be devastating $[6,7]$.

The Baltic Sea has a very high proportion of non-indigenous species compared to the total number of species [8], in that respect ranking among the top 10 affected ecosystems worldwide [9]. Further, it is characterised by a very steep salinity gradient ranging from 2 in the north east (Bothnian Bay) to 31 at the transition zone to the North Sea in the west [10]. Such brackish-water seas, with overall low species richness, have been shown to be especially vulnerable to invasions [11]. Therefore, large areas of the Baltic Sea as well as the Kiel Canal, an artificial brackish waterway, can be regarded as high risk areas for the establishment of non-indigenous species. This is especially so as the $98 \mathrm{~km}$ long Kiel Canal, which connects the North Sea to the SW Baltic Sea, is the busiest 
artificial water way in the world with approx. 80 container ships passing on a daily basis $[12,13]$.

An example of a very potent invasive species is the hydrozoan jellyfish Blackfordia virginica (Mayer, 1910) [14] Leptothecata (Cnidaria: Hydrozoa) cf. Cornelius $[15,16]$. B. virginica is characterised by a metagenic life history strategy with an alternation between a sexually reproducing medusa and an asexually reproducing polyp population to complete the life cycle. The pelagic medusa stage has been found in brackish-water systems (as reviewed in [17]), while the polyp stage has been confirmed from brackish-water systems, estuaries as well as coastal salt water swamps (e.g. as reviewed in [17]). The origin of this hydromedusa is not clear. It was first described by Mayer [14] based on dense accumulations in Virginia, USA during autumn 1904, but later molecular analyses documented a low genetic diversity, suggesting that animals went through a bottleneck, as expected during the translocation process of a non-indigenous species [18]. Thiel found that B. virginica was a common member of the hydromedusa community of the Black Sea, which suggests that it is actually native to the Black Sea region [19-22]. Apart from these early records, established B. virginica populations were found in other areas around the world e.g. India [23, 24], South America (e.g. $[17,25])$, North America [20, 22], South Africa [26], and southwestern Europe (e.g. [27]). For the Atlantic coast of southwestern Europe, B. virginica was first recorded in 1971 in the Loire estuary, Bay of Biscay, France [28]. In 1984 B. virginica was further observed in the Mira estuary, Portugal [29], while more recently, animals were recorded in the harbour of Amsterdam, Netherlands [30] and in the Gironde estuary, France [27]. In this study we describe the first record of Blackfordia virginica in the Kiel Canal and Kiel Fjord in the southwestern Baltic Sea. Furthermore, we collate long term ichthyoplankton survey data, analysed for gelatinous macrozooplankton, to set a baseline confirming presence and absence of Blackfordia virginica medusae. Especially the Baltic Sea, one of the largest brackish-water systems of the world, presents a highly suitable habitat for $B$. virginica, with a potential for severe ecosystem impacts due to grazing on zooplankton standing stocks.

\section{Methods}

\section{Sampling of hydromedusae}

The presence and absence of Blackfordia virginica has been confirmed as part of ongoing gelatinous macrozooplankton monitoring initiatives within 4 different sampling programs or survey activities of ichthyoplankton in the Baltic Sea and Kiel Canal (see detailed description of the individual programs below), covering the past 10 years (2008-2017, see Fig. 1, Additional file 1: Table S1 for station reference). Presented size distribution data of B. virginica are based on $4 \%$ borax buffered formaldehyde seawater solution without considering shrinkage effects.

\section{Kiel Canal}

Sampling was conducted at the monitoring station NOK (WGS84 coordinates: N54.343, E9.968) which is located at the eastern end of the Kiel Canal at kilometer 85, approx. $13 \mathrm{~km}$ west of the exit to the Baltic Sea, at weekly or monthly intervals covering the years 2010-2017. To characterise physical properties of the water column, salinity and temperature profiles were taken using the hand held CTD 48 M (Sea \& Sun Technology GmbH, Trappenkamp, Germany). Gelatinous macrozooplankton was sampled as part of an ongoing ichthyoplankton monitoring program using double oblique bongo net tows (60 $\mathrm{cm}$ diameter, 500 and $335 \mu \mathrm{m}$ mesh sizes) through the entire water column. Filtered volumes were calculated based on flowmeter recordings (Hydrobios, Kiel, Germany) and ranged between 100 and $160 \mathrm{~m}^{3}$, depending on current strength in the canal. Throughout July-October 2017, no bongo net casts could be conducted. Therefore, bi-monthly presence during summer was determined by visual confirmations and net tows from land. During October 2017, quantitative samples were generated using three independent WP2-net casts (60 $\mathrm{cm}$ diameter, $200 \mu \mathrm{m}$ meshed) from $1 \mathrm{~m}$ above the bottom to the surface. To increase the filtered water volume for reliable count data, each of the three samples consisted of triplicate WP2-net tows which were pooled leading to 9 individual WP2-net casts. Filtered water volume was estimated from wire length and net opening of strictly vertical tows. For 2016 and 2017, all bongo samples, preserved in $4 \%$ borax buffered formaldehyde seawater solution, were analysed on a light table in the laboratory for gelatinous macrozooplankton abundance estimation, while for 2010-2015 non-preserved samples were analysed right after catch along with sorting of ichthyoplankton. Blackfordia virginica were measured to the nearest $\mathrm{mm}$ from preserved samples using a caliper, not accounting for shrinkage effects.

\section{Baltic Sea}

During August 2017, a comprehensive survey investigating the gelatinous zooplankton community of the Baltic Sea was conducted with R/V Alkor, covering the area from the SW Baltic off Flensburg to the northern Gotland Basin (Fig. 1, Additional file 1: Table S1). The investigation period is consistent with documented peak abundances of $B$. virginica in other invaded areas, such as the Atlantic coast of France [27]. We analysed $>300$ individual nets with filtered water volumes ranging between $100 \mathrm{~m}^{3}$ and $300 \mathrm{~m}^{3}$ net $^{-1}$ for a total of 


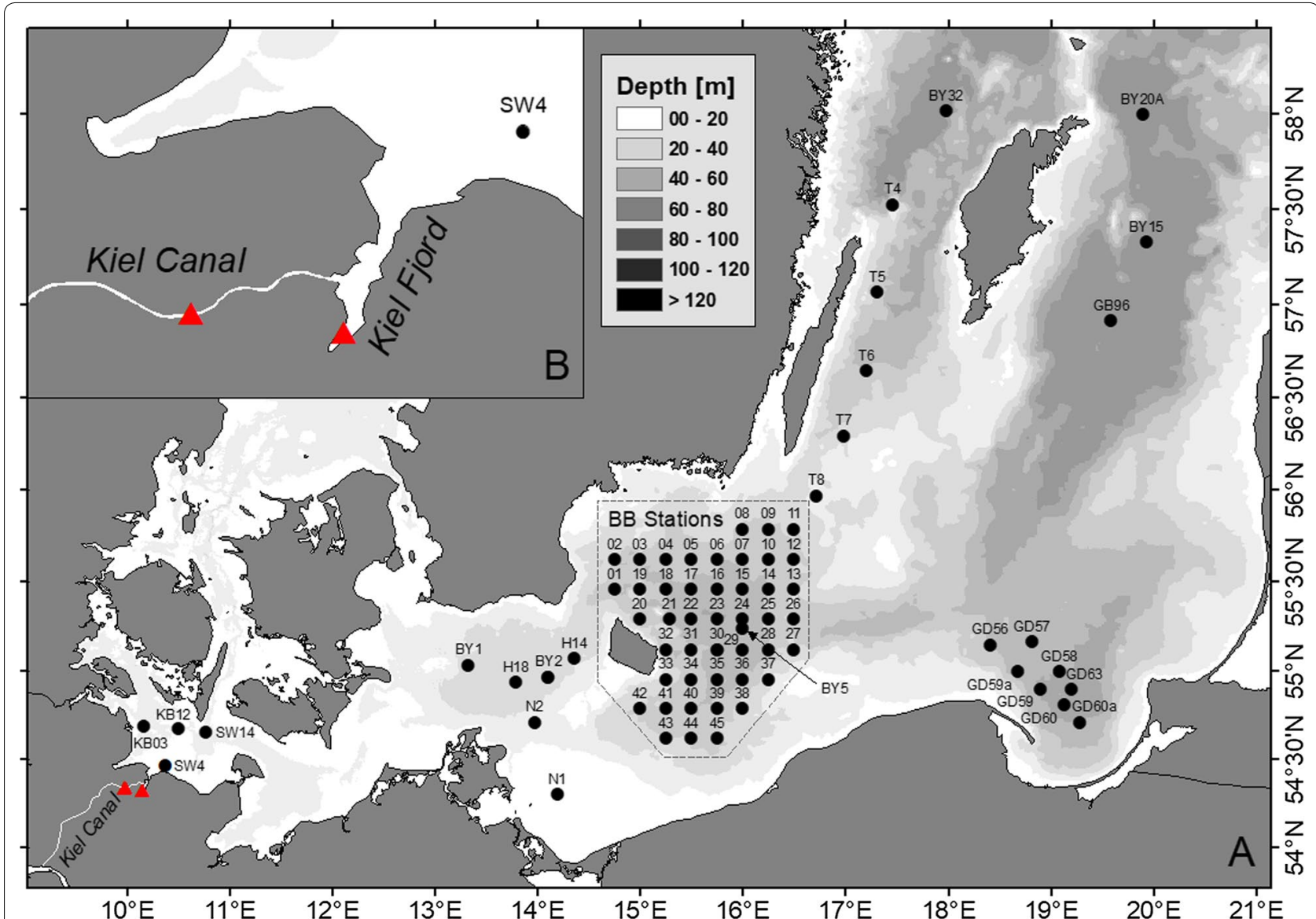

Fig. 1 Sampling stations which have been investigated for presence (red triangle) or absence (black circles) of the hydromedusa Blackfordia virginica in the Baltic Sea (73 stations investigated during August 2017), Kiel Canal (one station sampled from 2010 to 2017), qualitative sampling station in Kiel Fjord (September-October 2017) and the Bornholm Basin (45 BB stations during August 2008-2016, June 2010-2012 and $2014-2017$ and Sept. 2016, BB01-BB45)

75 stations, covering the entire water column down to $5 \mathrm{~m}$ above the bottom. We deployed different sampling gear consisting of (1) a bongo net equipped with 335 and $500 \mu \mathrm{m}$ meshed nets ( $\mathrm{n}=69$ casts), (2) a horizontally towed $335 \mu \mathrm{m}$ meshed Multinet Maxi (Hydrobios, Germany; $0.5 \mathrm{~m}^{2}$ net opening) with up to 9 individual nets $(\mathrm{n}=16$ casts) and (3) a horizontally towed $335 \mu \mathrm{m}$ meshed Multinet Midi (Hydrobios, Germany; $0.25 \mathrm{~m}^{2}$ net opening) with 5 individual nets ( $\mathrm{n}=8$ casts). Samples were analysed alive on a light table for all gelatinous macrozooplankton down to a size of $3 \mathrm{~mm}$.

\section{Kiel Fjord}

During September to October 2017, the Kiel Fjord was visually scanned from a floating Pier (WGS84 coordinates: N54.330, E10.150) for gelatinous macrozooplankton three times per week.

\section{Bornholm Basin}

Gelatinous macrozooplankton was investigated as part of an ichthyoplankton survey on a 45 station standard grid (BB 1-45, Fig. 1, Additional file 1: Table S1) in the Bornholm Basin (BB), Baltic Sea with R/V Alkor during August 2008, 2010, 2013 to 2015, R/V DANA during September 2015, as well as R/V Baltica during June from 2010 to 2017 (except 2013) using bongo net tows and analyses as described above.

\section{Species identification}

Identification of $B$. virginica was based on morphological characteristics using Mayer [14], analysing life material under a Leica stereomicroscope M125 (see Fig. 2 for morphological identification characteristics). Additionally, 13 specimens were sequenced for molecular species confirmation, see below for sampling infromation. DNA was extracted using the WIZARD Genomic Purification kit (Promega, Madison, USA) from tissue 


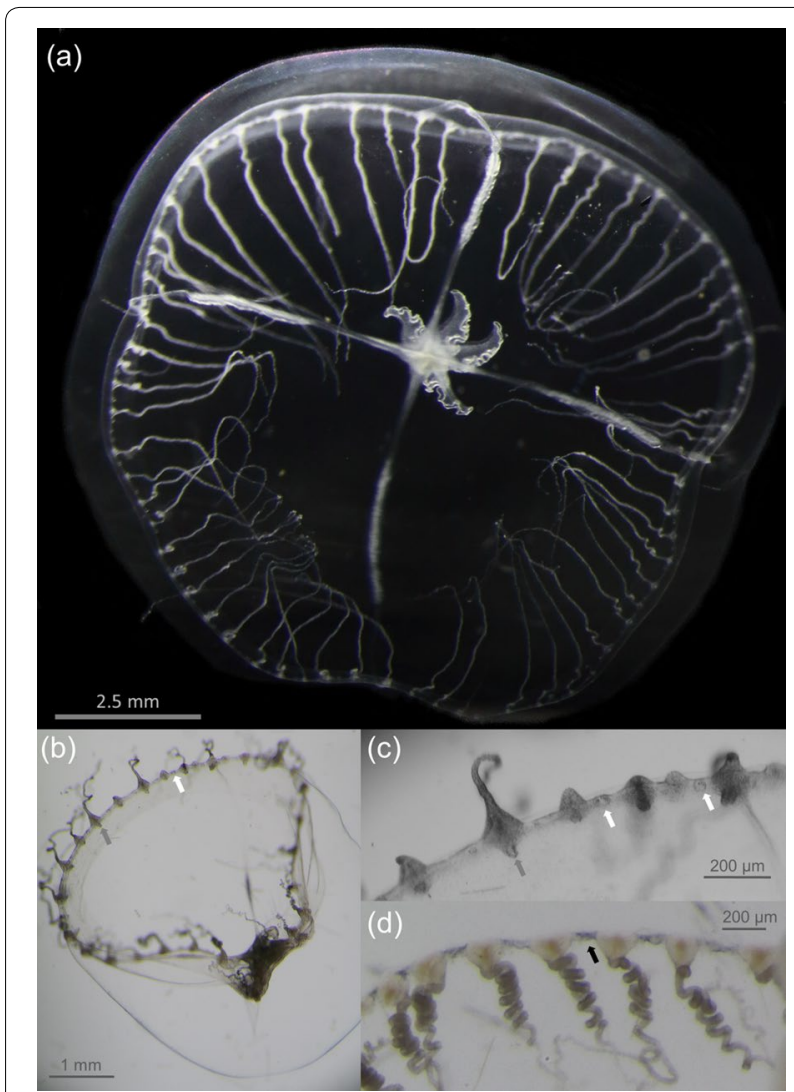

Fig. 2 The hydromedusa Blackfordia virginica (Mayer, 1910) [14] Leptothecata (Cnidaria: Hydrozoa) cf. Cornelius [15] (a), with hemispherical umbrella of max $22 \mathrm{~mm}$ in diameter, varying number of tentacles, depending on development stage, four radial canals and a quadratic manubrium with curved lips. Specific diagnostic characteristics include endodermal cores of tentacles which can project into the bell (grey arrow) (b), closed lithocysts with 1-3 concretions (white arrows) between adjacent tentacles (c), with grey pigmentation at their base (black arrow), even though this characteristic is not diagnostic for all B. virginica sub-populations (d), all images from living material

material of starved medusa, homogenised in $480 \mu \mathrm{L}$ $50 \mathrm{mM}$ EDTA with a pestle and incubated at $37{ }^{\circ} \mathrm{C}$ for 30 min after addition of Proteinase K (life technologies, Darmstadt, Germany), according to the manufacturers' protocol. DNA templates (100 ng) were subjected to PCR in $25 \mu \mathrm{L}$ total volume using the GoTaq DNA Polymerase kit (Promega, Madison, USA) and four different primer sets following published protocols [18, 31]. PCR reactions were used to determine the DNA sequences, performed by the sequencing facility at the Institute of Clinical Molecular Biology, University of Kiel, Kiel, Germany (IKMB). Sequence data were compared with GenBank deposits and used for species verification. The sequences obtained from this study are available on GenBank under the accession numbers: MH460957MH460960, gbr6607813.
Three specimens from Kiel Canal, after morphological identification and image verification of unpreserved material, were preserved in $4 \%$ buffered formalin solution and deposited at the Museum of University of Hamburg, Zentrum für Naturkunde (reference collection numbers ZMH C 12438-40). Animals were caught in the upper $50 \mathrm{~cm}$ of the water column from land (WGS84 coordinates: N54.345, E9.983) along Kiel Canal on the 28th of June 2017. Temperature $\left(18.4{ }^{\circ} \mathrm{C}\right)$ and salinity (10) was recorded and individual $B$. virginica caught using a ladle.

\section{Results}

Morphological analyses (Fig. 2) confirmed that the sampled species were Blackfordia virginica $[14,29]$. Further, sequence analyses with four primers of three different marker genes showed that the general $16 \mathrm{~S}$ sequences of sampled individuals were $100 \%$ identical to Blackfordia virginica (Mayer 1910) sequences retrieved from GenBank. Additional marker genes used showed a lower identify but $B$. virginica exclusively showed up as the top blast result for all markers employed. A 99\% identity was reached using the nuclear $18 \mathrm{~S}$ and mitochondrial COI sequences, while low query coverage (46\%) for the ITS-I marker resulted in an identity match with $B$. virginica of $98 \%$.

Blackfordia virginica was first observed in the Kiel Canal at the monitoring station NOK (WGS84 coordinates: N54.343, E9.968) during October 2014. The density was low, i.e. 0.7 ind. $\mathrm{m}^{-3}$ (Additional file 2: Table S2). The following year, animals were recorded in July, but starting in 2016, B. virginica was consistently present from June to October, reaching a maximum abundance of 5.1 ind. $\mathrm{m}^{-3}$ during July (Fig. 3). Even though animals were already recorded in April 2016, no animals were caught during four sampling campaigns during May and the first half of June. Similarly, during 2017 B. virginica appeared at the end of June reaching a density of 14.4 ind. $\mathrm{m}^{-3}$, and was consistently present until October. In summary, $B$. virginica has been present at the eastern side of the Kiel Canal since 2014, indicating established populations at the monitoring site since 2016.

During all sampling events, the overall size of $B$. virginica $(\mathrm{n}=1122)$ ranged between 2 and $17 \mathrm{~mm}$, based on formalin preserved samples without accounting for shrinkage. The average size of the $B$. virginica population at the Kiel Canal monitoring station during summer and autumn 2016 ranged between 6 and $9.5 \mathrm{~mm}$ (average \pm SD: $7.7 \pm 2.3 \mathrm{~mm}$, see Fig. 4). However, during the early first occurrence in April 2016, average sizes were much larger compared to all other sampling points, with an average size of $13.0 \pm 1.1 \mathrm{~mm}$. Only one formalin preserved sample from 2017 was analysed and its average size $(8.0 \pm 2.6 \mathrm{~mm} ; \mathrm{n}=290)$ in June was 

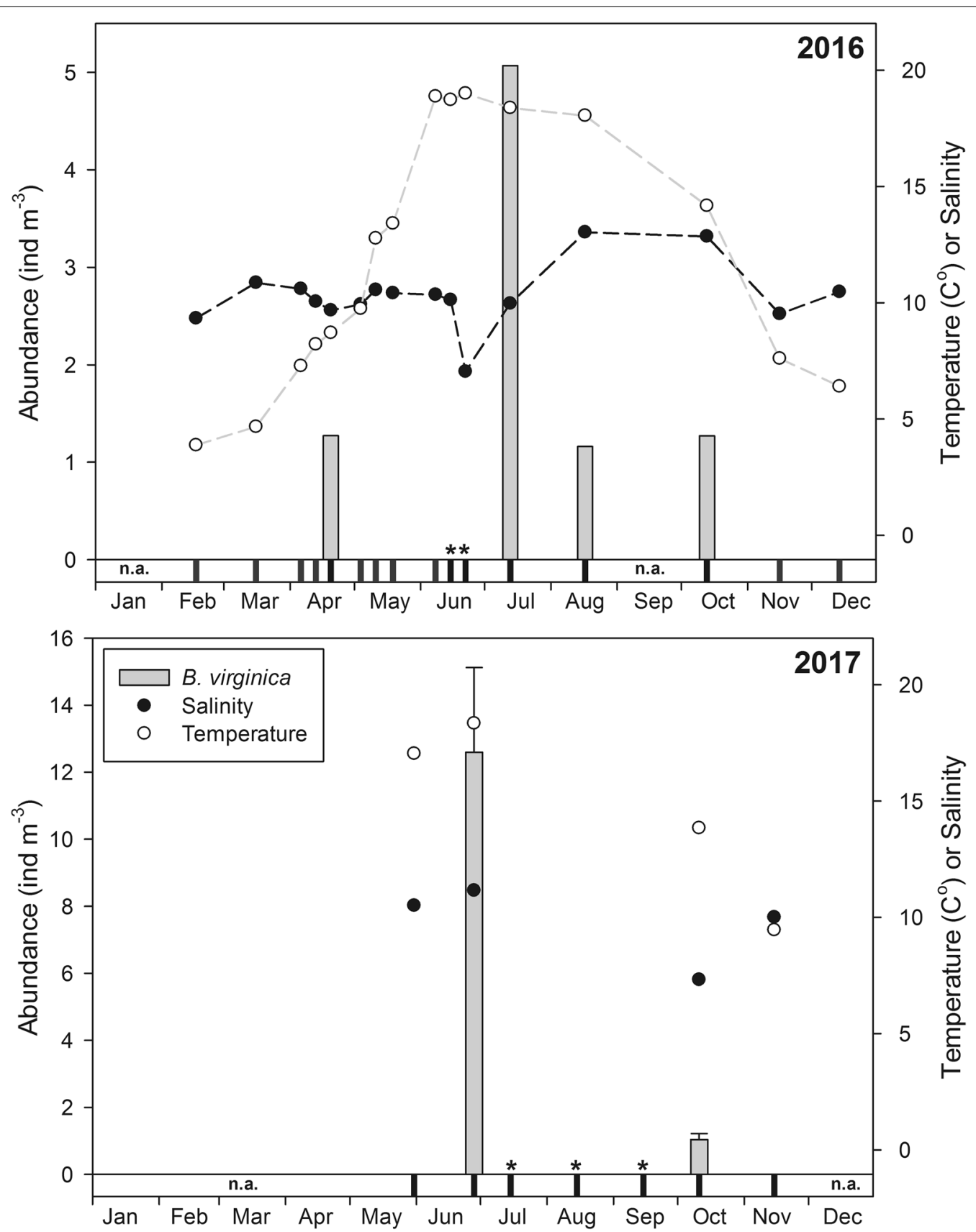

Fig. 3 Seasonal variation of Blackfordia virginica (Mayer, 1910) densities (ind. $\mathrm{m}^{-3} \pm$ SD) with average temperature (white dots) and salinity (black dots) conditions in Kiel Canal for the years 2016-2017, when animals were first recorded over a longer time period. First sightings from Oct. 2014 and July 2015 are not shown. Sampling time points (black bars) are shown, with non-quantitative presence indicated by asterisks $\left({ }^{*}\right)$. Note n.a. $=$ no data

comparable to the summer 2016 average values (Fig. 4, Additional file 2: Table S2). It is worth noting that during the last occurrence of B. virginica in the Kiel Canal during October 2016, before animals disappeared from the water column (Fig. 3), a much higher proportion of very small sized medusae contributed to the population structure. Blackfordia virginica were usually present at temperatures above $14{ }^{\circ} \mathrm{C}$, while only once (April 2016) specimens were found at $8.7^{\circ} \mathrm{C}$. Salinity did not seem to be a major contributor determining the presence or absence of $B$. virginica in the Kiel Canal within the salinity range from 7 to 13 (Fig. 5). 


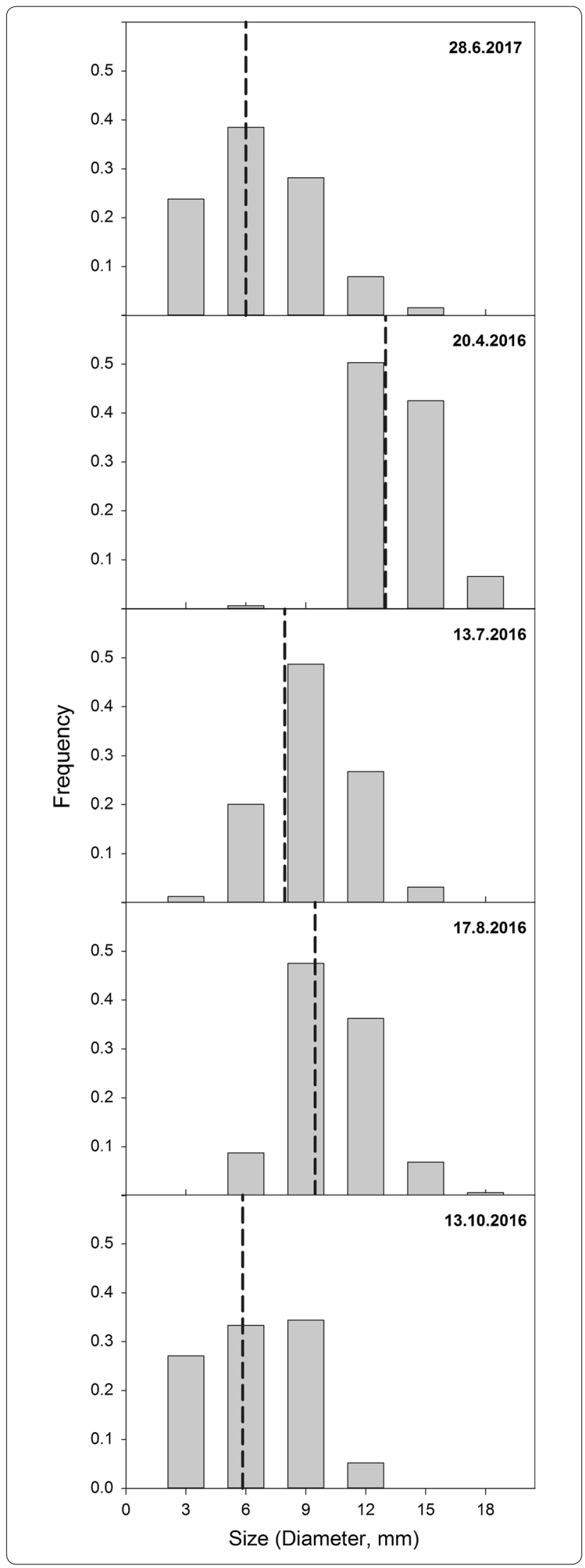

Fig. 4 Size-frequency distribution of Blackfordia virginica (Mayer, 1910) from Kiel Canal for the year 2016 and one time point in 2017. Grey bars present $3 \mathrm{~mm}$ size bins with overall average indicated by dashed line, all from preserved material, without accounting for shrinkage

We caught a single individual of $B$. virginica with an approximate life size of $10 \mathrm{~mm}$ in the Kiel Fjord, southwestern Baltic Sea, on 9 October 2017 at a salinity of 14.1 and a temperature of $14.3^{\circ} \mathrm{C}$. So far this non-indigenous hydrozoan species has not been observed elsewhere in the wider Baltic Sea area, irrespective of intensive monitoring activities during the past 10 years (Fig. 1, Additional file 1: Table S1). A full account of station information with absence records of B. virginica $(\mathrm{n}=660$ sampling stations) covering the years 2008 to 2017 is given in Additional file 1: Table S1.

\section{Discussion}

We describe the first record of the hydromedusan jellyfish Blackfordia virginica from northern Europe, namely Kiel Canal and Kiel Fjord, southwestern Baltic Sea. So far, standardised sampling of gelatinous zooplankton in other parts of the Baltic Sea has not detected the species during the past 10 years. The persistent presence of medusae populations during summer/autumn and seasonal variation in their size distribution in Kiel Canal indicate active recruitment throughout summer since 2016.

Concerning the question of the initial introduction vector to the Kiel Canal, there is no direct evidence. Shipping has been suggested to be the major cause for the primary introduction of non-indigenous species in the marine realm, both due to ballast water release and from fouling communities on ship hulls [9]. No ballast water release takes place in Kiel Canal and the water exchange with the North Sea and Baltic Sea is limited. Hence, it is most likely that $B$. virginica has been introduced as part of a fouling community on container ships. Kiel Canal is the most navigated, busiest artificial shipping route worldwide with 32,100 commercial ship passages in 2015. In comparison, Panama and Suez Canals had commercial ship passages of 14,000 and 17,500, respectively [13].

The occurrence of B. virginica in Kiel Canal ranged over a salinity gradient from 7 to 13 . In other invaded areas of southwestern Europe, B. virginica has been observed in near fresh water conditions [27] and up to a salinity of 27.5 [32]. Similarly, in south American estuaries of Brazil, medusae have been documented to occur over a very large salinity range from 2.2 to 36 [25]. This indicates that $B$. virginica is a truly euryhaline species, which successfully invaded a multitude of estuaries and 


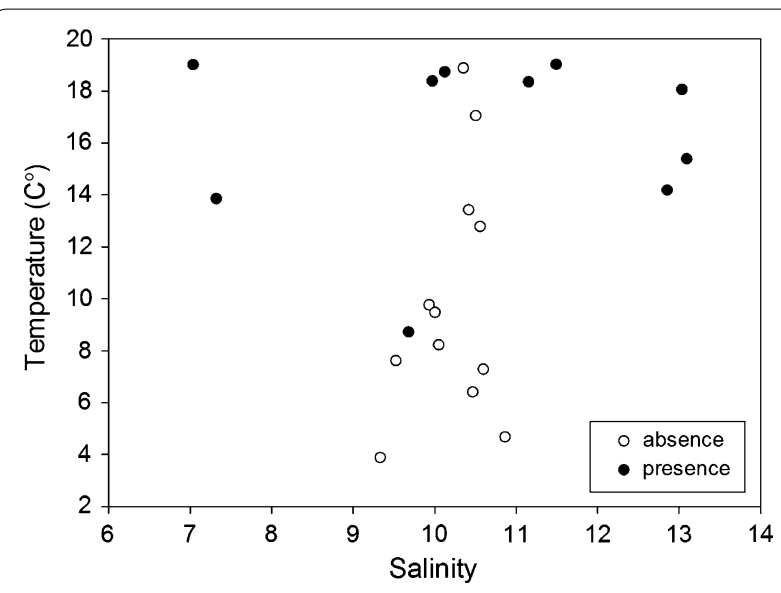

Fig. 5 Occurrence of Blackfordia virginica (Mayer, 1910) as a function of salinity and temperature with presence (black dots, $n=10$ for 2014-2017) and absence (white dots, $n=12$ for 2016/2017)

brackish-water systems around the world (for review see [27]). It also suggests that the species has a high potential to colonise most of the Baltic Sea.

In other areas of Europe, the peak abundance of B. virginica medusa occurs in summer [27, 32]. For example, in Portugal, the species occurred at temperatures above $12{ }^{\circ} \mathrm{C}$ [32] and similarly, in Gironde Estuary, France between 14.5 to $26.6{ }^{\circ} \mathrm{C}$ [27]. In the US, the species has been observed at temperatures above $16.5{ }^{\circ} \mathrm{C}$ [33]. In Kiel Canal, animals were recorded at temperatures above $14{ }^{\circ} \mathrm{C}$, matching what has been observed elsewhere. One observation where animals were recorded at a temperature of $8.7 \pm 0.3{ }^{\circ} \mathrm{C}$ (on 20 April 2016) is exceptional. The observed specimen were mostly large-sized, with an average size being twice as large as observed during the first occurrence in 2017. This suggests that they were produced and grew up in warmer (possibly shallower) sections of the Kiel Canal and subsequently drifted to our sampling station. This is further supported by the observation that $B$. virginica disappeared from the sampling station for 1.5 months and was first recorded again by mid June, when animals remained in Kiel Canal throughout summer and autumn. During October 2016, an extraordinary shift in the size distribution along with peak abundance of very small medusae were observed, which may be caused by a new cohort, which did not manage to grow up due to temperature effects. This has similarly been observed in the Gironde estuary, France, where $70 \%$ of the population consisted of $2 \mathrm{~mm}$ sized $B$. virginica during October before medusae disappeared from the water column [27].

B. virginica is a hydromedusa, characterised by an alternation between benthic and pelagic life forms. Medusa production from benthic polyps has been suggested to occur throughout the entire summer period in northwestern
America [20,34]. Locations of polyp settling in Kiel Canal remain to be identified. However, recurrent introductions due to ship hull fouling are not likely to have led to the high B. virginica medusa densities observed during recent years. Additionally, the change in size-frequency distribution further indicates an active recruitment at the sampling site in Kiel Canal during summer and autumn, similar to observations in northwestern America [20].

We further confirm B. virginica from Kiel Bight. This indicates that the high abundances in the Kiel Canal are likely to have seeded animals into the southwestern Baltic Sea, but it remains to be seen if they establish permanent populations in this area. During summer, water temperatures in the Baltic Sea are within the preferred temperature range of B. virginica in Kiel Canal and other invaded areas around the world. This suggests that the Baltic Sea offers ample opportunities for the establishment of self-recruiting populations. Furthermore, rocky coastlines offer plenty of hard substrate for the settlement of polyps, along with the additional availability of hard substrate as a consequence of increasing offshore wind farm structures in the Baltic Sea. We therefore suggest that $B$. virginica can be regarded as a highly potent non-indigenous species with a large colonisation potential for the Baltic Sea. In other areas of Europe, it has been documented that high abundances of $B$. virginica (650 to 1700 ind. $\mathrm{m}^{-3}$ ) have a negative impact on food web structure and functioning [27, 35]. Blackfordia virginica pose a high grazing pressure on local zooplankton standing stocks [32] as well as fish larvae [33]. The latter is further confirmed by non-quantitative observations from Kiel Canal during summer where a high percentage of $B$. virginica with ingested gobiid fish larvae were observed (Jaspers, Wendt pers. observation). Therefore, it can be expected that a further spreading and abundance increase of $B$. virginica may not only result in food competition with local pelagic fish stocks but additionally cause direct predation on fish early life stages. Particularly, this may pose a high risk if $B$. virginica is spreading further into the Baltic Sea and reaches the deeper areas like the Bornholm, Gdansk and Gotland basins, as these are the major spawning grounds of commercially important fish stocks such as sprat and cod. A similar impact on early life stages of fish had been hypothesised when another non-indigenous comb jelly, Mnemiopsis leidyi, was first recorded in the Baltic Sea. Even though M. leidyi is holoplanktonic, they do not form self-sustaining populations in most areas of the Baltic Sea due to salinity constraints on reproduction rates [36]. Therefore, the spatio-temporal overlap with early life stages of commercially important fish is limited [37]. In contrast, the present study shows that $B$. virginica is not constrained by low salinity and occurs in the Kiel Canal from early summer throughout autumn. Therefore, negative impacts on fish recruits could be expected via 
food competition as well as direct predation, especially for coastal areas of the Baltic, where e.g. herring is spawning [38]. This highlights that the new record of this non-indigenous species in northern Europe is a matter of concern for low saline environments.

In addition to the finding of $B$. virginica medusae, the nonindigenous comb jelly Mnemiopsis leidyi was observed twice during the 8 year investigation period in Kiel Canal. This is the first record of M. leidyi in Kiel Canal. Specifically, animals were recorded during September 2010 and December 2015, but at low densities of 0.1 and 0.01 ind. $\mathrm{m}^{-3}$, when the average salinity was $10.7 \pm 0.1$ and $10.8 \pm 2.7$, respectively (pers. comm. Jaspers). This occasional occurrence of $M$. leidyi in the Kiel Canal indicates that animals do not form self-sustaining populations there. This is likely due to the low salinity, which is below the threshold where M. leidyi do reproduce and multiply $[36,39]$. The exceptional high salinity observed during the recordings of $M$. leidyi in the Kiel Canal further indicates that those animals are likely to be seeded from the Kiel Bight via inflow of higher saline waters. This is further substantiated as M. leidyi was present in Kiel Bight during that time period [40].

Some invasive jellyfish e.g. Phyllorhiza punctata, Cassiopea andromeda, Rhopilema nomadica, Aurelia spp. [41], as well as the comb jelly Mnemiopsis leidyi [42], are well known to reach a global distribution and to have large impact on local ecosystems. Nevertheless, they remain under-represented in ongoing monitoring activities and non-indigenous species databases. This inconsistency is primarily attributed to the overall lack of systematic long term data acquisition for gelatinous macrozooplankton [43]. In this study, we have used a comparable methodology over an investigation period of ca. 10 years covering large areas of the Baltic Sea. We highlight that monitoring activities including less well studied organism groups such as gelatinous zooplankton are important to establish baselines for the detection of nonindigenous species at an early stage of their colonisation. Further, we conclude that not only large gelatinous zooplankton species such as Mnemiopsis leidyi or Phyllorhiza punctata are a matter of concern as non-indigenous species, but also small species such as B. virginica. The Baltic Sea, especially coastal areas, constitutes suitable habitat for $B$. virginica and the Baltic Sea is thus confronted with a high invasion risk for this non-indigenous jellyfish species.

\section{Additional files}

Additional file 1: Table S1. Blackfordia virginica medusae (Mayer, 1910) presence/absence data from the Baltic Sea covering the years 2008 to 2017.

Additional file 2: Table S2. Blackfordia virginica medusae (Mayer, 1910) recordings at the monitoring station in the Kiel Canal with abundance, temperature and salinity measurements $( \pm \mathrm{SD})$ for the respective sampling points. (DOCX $17 \mathrm{~kb})$

\section{Authors' contributions}

$\mathrm{CJ}, \mathrm{BH}, \mathrm{CC}$ conducted the surveys and analysed the samples, NWB conducted molecular analyses, $\mathrm{CJ}$ analysed the data and wrote the manuscript; $\mathrm{BH}, \mathrm{NWB}$, CC commented on the final version of the manuscript. All authors read and approved the final manuscript

\section{Author details}

${ }^{1}$ Evolutionary Ecology of Marine Fishes, GEOMAR - Helmholtz Centre for Ocean Research Kiel, Düsternbrooker Weg 20, 24105 Kiel, Germany. ${ }^{2}$ National Institute of Aquatic Resources, Technical University of Denmark, DTU Aqua, Kemitorvet, Building 202, 2800 Kgs. Lyngby, Denmark. ${ }^{3}$ Institute for General Microbiology, Christian-Albrechts-Universität zu Kiel, Am Botanischen Garten 1-9, Kiel, Germany.

\section{Acknowledgements}

We would like to thank the RN Alkor crew and MNF-301 students for technical support and assistance during sample processing of the AL499 cruise, the coastal research vessel Polarfuchs and their crew for help during sampling as well as Ramona Beckmann, Matthias Paulsen, Christian Hesse, Luise Töpfer, Jesco Peschutter, Anna Anschütz, Henrik Gross and Fabian Wendt for collecting and analyzing samples from the Kiel Canal and Martin Fischer for sequence data deposition. Special thanks are due to Prof. T.B.H. Reusch and Prof. R. Schmitz-Streit for supporting this project in their laboratories.

\section{Competing interests}

The authors declare that they have no competing interests.

\section{Availability of data and materials}

All data are deposited on PANGAEA (https://doi.org/10.1594/PANGAEA.89131 6) and GenBank (accession numbers: MH460957-MH460960, gbr6607813).

\section{Consent for publication}

The authors declare that they consent to publish in this journal.

\section{Ethics approval and consent to participate}

All applicable national guidelines for the care and use of animals were followed.

\section{Funding}

The study received financial support from the Danish Council for Independent Research and Marie Curie (DFF-Mobilex Grant Number: DFF-1325-00102B to $\mathrm{CJ}$ ), the SFB 1182 (CJ), the DFG Aquashift project RECONN (CC) as well as a Research and Development contract with the Government of Schleswig-Holstein - LLUR (CC).

\section{Publisher's Note}

Springer Nature remains neutral with regard to jurisdictional claims in published maps and institutional affiliations.

Received: 23 February 2018 Accepted: 20 June 2018

Published online: 01 August 2018

\section{References}

1. Richardson AJ, Bakun A, Hays GC, Gibbons MJ. The jellyfish joyride: causes, consequences and management responses to a more gelatinous future. Trends Ecol Evol. 2009;24(6):312-22.

2. Lodge DM. Biological invasions - lessons for ecology. Trends Ecol Evol. 1993;8(4):133-7.

3. Stachowicz JJ, Terwin JR, Whitlatch RB, Osman RW. Linking climate change and biological invasions: Ocean warming facilitates nonindigenous species invasions. Proc Natl Acad Sci USA. 2002;99(24):15497-500.

4. Seebens $\mathrm{H}$, et al. No saturation in the accumulation of alien species worldwide. Nat Commun. 2017;8:14435.

5. Williamson M, Fitter A. The varying success of invaders. Ecology. 1996;77(6):1661-6.

6. Dias PJ, et al. Establishment of a taxonomic and molecular reference collection to support the identification of species regulated by the Western 
Australian prevention list for introduced marine pests. Manag Biol Invasion. 2017;8(2):215-25.

7. Lowe S, Browne M, Boudjelas S, De Poorter M. 100 of the world's worst invasive alien species: a selection from the global invasive species database. Aukland: Hollands Printing Ltd; 2000. p. 1-12.

8. Leppäkoski E, et al. The Baltic: a sea of invaders. Can J Fish Aquat Sci. 2002;59(7):1175-88

9. Molnar JL, Gamboa RL, Revenga C, Spalding MD. Assessing the global threat of invasive species to marine biodiversity. Front Ecol Environ. 2008;6(9):485-92.

10. Herlemann DPR, Labrenz M, Jurgens K, Bertilsson S, Waniek JJ, Andersson AF. Transitions in bacterial communities along the $2000 \mathrm{~km}$ salinity gradient of the Baltic Sea. ISME J. 2011;5:1571-9.

11. Paavola M, Olenin S, Leppäkoski E. Are invasive species most successful in habitats of low native species richness across European brackish water seas? Estuar Coast Shelf Sci. 2005:64(4):738-50.

12. Gollasch $S$, Rosenthal H. The Kiel Canal: the world's busiest man-made waterway and biological invasions. In: Gollasch S, Galil BS, Cohen AN, editors. Bridging divides: maritime chanals and invasion corridors. Dordrecht: Springer; 2006. p. 5-89.

13. Krause A. Fakten und Zahlen zur maritimen Abhängigkeit der Bundesrepublik Deutschland, Jahresbericht 2016. 2016 Dezernat Handelsschifffahrt/Marineschifffahrtleitung, Hamburg, p. 1-273.

14. Mayer AG. Medusae of the world: the hydromedusae. Washington, D.C. Carnegie institution of Washington; 1910. p. 132-498.

15. Cornelius PFS. Medusa loss in leptolid Hydrozoa (Cnidaria), hydroid rafting, and abbreviated life-cycles among their remote-island faunae: an interim review. Sci Mar. 1992;56:245-61.

16. Maronna MM, Miranda TP, Peña Cantero ÁL, Barbeitos MS, Marques AC. Towards a phylogenetic classification of Leptothecata (Cnidaria, Hydrozoa). Sci Rep. 2016:6:18075.

17. Bardi J, Marques AC. The invasive hydromedusae Blackfordia virginica Mayer, 1910 (Cnidaria: Blackfordiidae) in southern Brazil, with comments on taxonomy and distribution of the genus Blackfordia. Zootaxa. 2009:2198:41-50.

18. Harrison GF, Kim K, Collins AG. Low genetic diversity of the putatively introduced, brackish water hydrozoan, Blackfordia virginica (Leptothecata: Blackfordiidae), throughout the United States, with a new record for Lake Pontchartrain, Louisiana. Proc Biol Soc Wash. 2013;126(2):91-102.

19. Thiel ME. Zur Kenntnis der Hydromeduseanfauna des Schwarzen Meeres. Zool Anz. 1935;11(7/8):160-75.

20. Mills CE, Sommer F. Invertebrate introductions in marine habitats: two species of hydromedusae (Cnidaria) natibe to the Black Sea, Maeotias inexspectata and Blackfordia virginica invade San Francisco Bay. Mar Biol. 1995;122(2):279-88.

21. Carlton JT. Transoceanic and interoceanic dispersal of coastal marine organisms: the biology of ballast water. Oceanogr Mar Biol Annu Rev. 1985;23:313-72.

22. Mills $C E$, Rees JT. New observations and corrections concerning the trio of invasive hydromedusae Maeotias marginata (= M. inexpectata), Blackfordia virginica and Moerisia sp in the San Francisco Estuary. Sci Mar. 2000;64:151-5.

23. Vannucci M, Santhakumari V, Dos Santos EP. The ecology of hydromedusae from the Cochin. area. Mar Biol. 1970;7:49-58.

24. Kramp PL. Hydromedusae in the Indian Museum. Rec Indian Mus. 1958;53:339-76.

25. Freire M, Genzano GN, Neumann-Leitao S, Perez CD. The non-indigenous medusa Blackfordia virginica (Hydrozoa, Leptothecata) in tropical Brazil: 50 years of unnoticed presence. Biol Invasions. 2014;16(1):1-5.

26. Buecher E, Goy J, Gibbons M. Hydromedusae of the Agulhas current. African Invertebr. 2005;46:27-69.
27. Nowaczyk A, et al. Spatial and temporal patterns of occurrence of three alien hydromedusae, Blackfordia virginica (Mayer, 1910), Nemopsis bache (Agassiz, 1849) and Maeotias marginata (Modeer, 1791), in the Gironde Estuary (France). Aquat Invasions. 2016;11(4):397-409.

28. Denayer JC. 3 new or little known medusae of french coasts - Maeotis inexpectata, Ostrooumov, 1896; Blackfordia virginica, Mayer, 1910; Nemopsis bachei, Agassiz, 1849. Cah Biol Mar. 1973;14(3):285.

29. Moore SJ. Redescription of the Leptomedusan Blackfordia virginica. J Mar Biol Assoc UK. 1987:67(2):287-91.

30. Faasse M, Melchers M. The exotic jellyfish Blackfordia virginica introduced into the Netherlands (Cnidaria: Hydrozoa). Nederlandse Faunistische Mededelingen. 2014;43:103-10

31. Schroth W, Jarms G, Streit B, Schierwater B. Speciation and phylogeography in the cosmopolitan marine moon jelly. Aurelia sp. BMC Evol Biol. 2002;2(1):1-10.

32. Marques F, Chainho P, Costa JL, Domingos I, Angelico MM. Abundance, seasonal patterns and diet of the non-native jellyfish Blackfordia virginica in a Portuquese estuary. Estuar Coast Shelf Sci. 2015;167:212-9.

33. Wintzer AP, Meek MH, Moyle PB. Abundance, size, and diel feeding ecology of Blackfordia virginica (Mayer, 1910), a non-native hydrozoan in the lower Napa and Petaluma Rivers, California (USA). Aquat Invasions. 2013;8(2):147-56.

34. Wintzer AP, Meek MH, Moyle PB, May B. Ecological insights into the polyp stage of non-native hydrozoans in the San Francisco Estuary. Aquat Ecol. 2011;45(2):151-61.

35. Marques $F$, et al. Ecological aspects and potential impacts of the nonnative hydromedusa Blackfordia virginica in a temperate estuary. Estuar Coast Shelf Sci. 2017;197:69-79.

36. Jaspers C, Møller LF, Kiørboe T. Salinity gradient of the Baltic Sea limits the reproduction and population expansion of the newly invaded comb jelly Mnemiopsis leidyi. PLOS ONE. 2011;6(8):e24065.

37. Schaber M, et al. Spatio-temporal overlap of the alien invasive ctenophore Mnemiopsis leidyi and ichthyoplankton in the Bornholm Basin (Baltic Sea). Biol Invasions. 2011;13(12):2647-60.

38. Von Dorrien C, et al. A review on the Herring Clupea harengus (Actinopterygii: Clupeiformes: Clupeidae) recruitment and early life stage ecology in the western Baltic Sea. Acta Ichthyol Pisc. 2013;43(3):169-82.

39. Jaspers C, Haraldsson M, Lombard F, Bolte S, Kiørboe T. Seasonal dynamics of early life stages of invasive and native ctenophores give clues to invasion and bloom potential in the Baltic Sea. J Plankton Res. 2013;35(3):582-94.

40. Jaspers $C$, et al. Ocean current connectivity propelling the secondary spread of a marine invasive comb jelly across western Eurasia. Global Ecol Biogeogr. 2018. https://doi.org/10.1111/geb.12742.

41. Graham WM, Bayha KM. Biological invasions by marine jellyfish, chap. 14. In: Nentwig W, editor. Biological invasions, ecological studies, vol. 193. Berlin: Springer; 2007. p. 239-50.

42. Costello JH, Bayha KM, Mianzan HW, Shiganova TA, Purcell JE. Transitions of Mnemiopsis leidyi (Ctenophora: Lobata) from a native to an exotic species: a review. Hydrobiologia. 2012;690(1):21-46.

43. Condon $\mathrm{RH}$, et al. Questioning the rise of gelatinous zooplankton in the world's oceans. BioScience. 2012;62(2):160-9.

Ready to submit your research? Choose BMC and benefit from:

- fast, convenient online submission

- thorough peer review by experienced researchers in your field

- rapid publication on acceptance

- support for research data, including large and complex data types

- gold Open Access which fosters wider collaboration and increased citations

- maximum visibility for your research: over 100M website views per year

At BMC, research is always in progress.

Learn more biomedcentral.com/submissions 